\title{
Empirical Substantiation of Sport Trademark Dilution: Quasi-Experimental Examination of Dilutive Effects
}

\begin{abstract}
Sungho Cho
Trademark dilution law provides mark owners with another federal claim against unauthorized users in addition to the traditional claim for infringement. While dilution law has become a major vehicle of trademark enforcement for many branding companies, its rationale has been criticized by scholars, particularly, in terms of the ambiguous concept of the harm allegedly cause by dilution. Given the issue, this study examined whether dilutive use of famous sport trademarks has substantially harmful effects on the distinctive psychological value of the senior marks. It first attempted to develop an ad hoc measurement solution based on Keller's (1993) brand equity theory. A follow-up quasi-experimental study examined the impact of given dilutive information. The result shows that a majority of the senior marks revealed substantially increased brand equity scores rather than decreased value. The result suggests that the harm argued in light of dilution theory is questionable, which calls for more empirical proofs.
\end{abstract}

The Lanham Act (2012) provides owners of legally protected trademarks with a legal cause of action against others who use deceptively similar marks in commerce that are likely to confuse consumers. The law was designed to protect the general public from being confused as to sources of goods or services (Lemley, 1999). Thus, plaintiffs must prove the likelihood of confusion as an element for the claim (Kahn, 2004). Such notion has remarkably expanded since the enactments of Trademark Dilution Act of 1995 (Thurmon, 2009). The law now protects not only general consumers but also owner's brand equity (Magid, Cox, \& Cox, 2006), brand awareness and image (Keller, 1993).

Given the expanded legal paradigm, sport branding companies have become more vigilant and aggressive in enforcing their trademark rights. In 2007, Nike brought a lawsuit to enjoin a vendor that was selling biotech laboratory supplies from using a similar mark, Nikepal (Nike, Inc. v. Nikepal, Inc., 2007). Without the enhanced protection under the dilution statute, the case might have been more challenging for Nike because the traditional claim of trademark infringement requires proof of likelihood of confusion, meaning, an appreciable number of consumers

Cho (scho@bgsu.edu) is with the School of HMSLS, Bowling Green State University, Bowling Green, $\mathrm{OH}$. 
are likely to believe that the biotech laboratory supplies are sold by or somehow closely affiliated to Nike. Under the dilution statute, the court decided in favor of Nike and granted a permanent injunction (Nike, Inc. v. Nikepal, Inc., 2007).

On the other hand, adidas had a partial victory against Herbalife after a prolonged dispute over their brand logos [i.e., Trefoil (adidas) and Tri-Leaf (Herbalife)]. In 1998, the parties agreed upon that Herbalife would not use its Tri-Leaf logo on products or services proximate to adidas' core goods (adidas v. Herbalife, Inc., 2010). In 2007, Herbalife entered into a sponsorship agreement with L.A. Galaxy with which adidas also maintained sponsorship rights. adidas sued Herbalife for breach of contract and trademark dilution (adidas America, Inc. v. Herbal Life International, Inc., 2009). Although adidas won a series of summary judgment for breach of contract and unfair competition, the court refused to grant a permanent injunction in light of eBay, Inc. v. Mercexchange (2006).

In $e B a y$, the U.S. Supreme Court opined that an injunctive remedy may not be automatically granted for infringement of intellectual property. Instead, the Court declared that all federal courts must examine the traditional test to decide whether an injunctive relief is proper (Weinbergerv. Romero-Barcelo, 1982; Amoco Production Co. v. Gambell, 1987). The test requires a plaintiff to demonstrate that: (1) it has suffered an irreparable injury; (2) remedies available at law are inadequate to compensate for that injury; (3) considering the balance of hardships between the plaintiff and defendant, a remedy in equity is warranted; and (4) the public interest would not be disserved by a permanent injunction (eBay, Inc. v. Mercexchange, 2006). Pursuant to $e B a y$, the adidas court concluded that the plaintiff failed to prove the first element (adidas v. Herbalife, Inc., 2012).

While trademark dilution claims under the federal law have become a primary legal weapon for powerful sport brands, commentators have criticized negative aspects of the law, e.g., doctrinal inconsistency between trademark dilution and infringement (Beebe, 2008; Beerline, 2008; Long, 2006; Vapnyar, 2003), anticompetitive characteristics of dilution law (Bradford, 2008), chilling effects on free expression (Curan, 2004; Lemley, 1999), elusive concept of alleged harm (Lemley, 1999; McKenna, 2009; Tushnet, 2008). In consideration of the debates centered on the rationale of the law, this study seeks to examine the controversial concept of the harm allegedly inflicted by trademark dilution. It empirically tests detrimental effects of junior marks on senior marks, if any, in terms of brand equity.

The following sections consist of four subparts. First, the theoretical background section highlights the importance of trademark law and its enforcement mechanism in the context of brand management. Two common legal claims (i.e., infringement and dilution) are introduced and compared in terms of their doctrinal foundations and public policy. It then explicates the elusive harm allegedly caused by trademark dilution and calls for an empirical inquiry to substantiate the theory of dilution. Second, the following section explains two independent empirical studies undertaken for the inquiry: (1) development of an ad hoc measurement scale; and (2) quasi-experimental design to examine dilutive effects of junior use on brand equity of senior marks. Third, results are reported. Fourth, the final section discusses theoretical and practical implications. Future research directions and limitations are identified. 


\section{Theoretical Background}

\section{Brand Management and Protection of Trademark}

Studies have highlighted the significance of trademark law and its enforcement in the context of brand management (Cho \& Moorman, 2014; George, 2005; Ohm, 2013; Le Péru, 2004). A brand is designed to designate a source of goods and deliver a favorable image. When it satisfies legal standards, it is recognized as a trademark. A fair amount of resources must be consumed to build a strong mark that can accurately designate the source of products and effectively conveys a desirable image (Aaker, 1991). If free-riders can easily take advantage of such valuable intellectual property without authorization, owners would lose incentives to maintain high quality products represented by their marks. Moreover, such unjust enrichment would disrupt one of the most foundational principles of capitalistic economy, fair competition. Given the legal protection, enforcement activities including trademark litigation constitute a crucial vehicle of brand management.

Young and Rubicam (2013) outline the fundamental elements of branding through the Brand Asset Valuator. The Brand Asset Valuator assesses brand strength based on a brand's power of differentiation. Brand strength is also dependent on how consumers view the brand as an attractive symbol. Lastly, a brand's stature portends consumers' involvement with the brand and the level of goodwill they would feel. Carefully planned consistent branding efforts are essential for successful brand management. In addition, the enforcement of trademark rights through the legal system is one of the most crucial tasks.

A brand as a legal entity can be in different forms. 15 U.S.C. $§ 1127$ (2006) defines a trademark as "any word, name, symbol, or device, or any combination ... to identify and distinguish his or her goods." In addition to a word or name, a catchphrase is a major form of branding that intends to convey desirable advertising messages connotatively. For instance, the slogan, "Nationwide is on your side," communicates that the insurance giant looks out for its customers on a personal level. The LPGA's slogan, "these girls can play," announced that the league, the golfers, and the tournaments they promote and play provide fans with an impressive spectator experience. Shoemaker New Balance, through their brand promise of "performance made in America," tells customers instantly that their brand of shoes is high-functioning and the company supports American labor.

While an advertising message that designates the source of products or services can be disseminated by a term or a selection of words, a well-established brand's essence can also be transmitted without words through a logo, crest, insignia, or trade dress. A pioneer of mass marketing Proctor and Gamble ("P\&G" hereafter) realized the value of branding through a logo as early as the late nineteenth century (Dyer, Dalzell, \& Olegario, 2004). Since a vast majority of the population was unable to read in the late $1800 \mathrm{~s}, \mathrm{P} \& \mathrm{G}$ placed a distinctive man-in-the-moon logo on their goods, so customers could identity their favorite $\mathrm{P} \& \mathrm{G}$ brand products by sight. Although logos were somewhat exceptional for commercial use in 1879, they are certainly a well-established genre of brand identity now without a doubt (Dyer, Dalzell, \& Olegario, 2004). 
A great deal of artistic proficiency as well as marketing expertise go into logo and trademark design, because they must contain a consequential symbolic message and constitute a lasting image of a company. For example, Nike's swoosh is one of the most recognizable trademarks in the world, which is, in essence, the international representative of the company. Coca-Cola, one of the most loyal sponsors of mega sport events, also has an instantly identifiable trademark (i.e., red disk that surrounds their name printed in distinctive script and makes consumers instantly think of the brand). When internal (e.g., shareholders; employees) and external (e.g., suppliers; customers) stakeholders see Nike and Coke logos, they likely have expectations that are communicated by and associated with those special symbols (Aaker, 1991). Thus, when the brand logos are used improperly for nonauthorized purposes, it may denigrate, defame, or dilute the distinctive value of brands.

The famous "We are all witness" campaign that Nike staged on behalf of LeBron James quickly descended into the "Quitness" joke upon James' decision to leave Cleveland and take his talents to South Beach. Coca-Cola's celebrated unique logo was also the earlier subject of a joke when its distinct script was mimicked to read Cocaine across its red disk. Not all improper usage of trademarks are jokerelated. The International Olympic Committee ("IOC" hereafter) took a serious tone when they ordered the publishing company, FIT, Inc., to cease and desist the use of the original Sport Marketing Quarterly ("SMQ" hereafter) cover design. Covers for the first four volumes of the SMQ displayed four interlocking rings to represent the Big 4 sports of baseball, basketball, football, and hockey as well as marketing's 4 P's of product, place, promotion, and price. The IOC claimed that the four rings were too close in appearance to the five interlocking color rings symbolizing the Olympic Games (Branch, personal communication, 2012). Although the designs appeared to be substantially different (e.g., 4 rings compared with 5, one color versus 5), the IOC was concerned enough with the similarity of the logos to initiate a legal action and the publisher agreed by the time of volume 5's arrival to redesign the SMQ's cover. As such, organizations with renowned trademarks have protected their marks at all costs.

Indeed, while services, products, and causes can be replicated by others, a brand is novel and forms what Beverland, Napoli, and Yakimkova (2007) termed a point-of-difference. Brands can distinguish themselves from competitors (Beverland, 2005), establish a reputation (Cretu \& Brodie, 2007), influence customers' perceptions (Knapp, 1999; Knapp, 2008), and even elevate a product to a premium status (Roberts, 2005; Roberts, 2006). Such power of famous brands is the unique value that trademark owners want to enhance and vigorously protect. As dilution law began to recognize the value of psychological properties associated with a brand by providing an additional legal claim, trademark dilution, contemporary owners of famous trademarks arguably have a significantly more favorable legal environment for the execution of their brand management strategies.

\section{Trademark Infringement and Dilution Claim}

\section{Trademark Infringement}

The Lanham Act, 15 U.S.C. $\$ 1051$ et seq., (hereinafter "Lanham Act") protects federally registered trademarks from unauthorized use of such marks and prohibits 
deceptive marketing that would create confusion as to sources of goods or services. Owners of protected marks may bring lawsuits against other parties who use their marks without permission if another person

use[s] in commerce any reproduction, counterfeit, copy or colorable imitation of a registered mark in conjunction with the sale . . . or in connection with which such use is likely to cause confusion or to cause mistake, or to deceive. (Lanham Act, 15 U.S.C. § 1114(1)(a), 2005)

In addition to the claim under Section 1114, Lanham Act prohibits false designation of origin of product or service (Lanham Act, 15 U.S.C. §1125, 2012). This provision basically prohibits unfair competition in a relevant market. Therefore, the scope of Section 1125 is significantly broader than above-mentioned Section 1114 (Grady \& McKelvey, 2008).

To prevail in an infringement case, a plaintiff must prove three elements: (1) ownership of protected trademark, (2) unauthorized use without consent, and (3) the use in contention is likely to cause consumer confusion (Cho \& Moorman, 2014). Many infringement cases hinge on the last element. Here the likelihood of confusion means "the probability that the accused infringer's mark is the legal cause in fact, of confused, mistaken or deceived states of mind of potential consumers" (Brogan, 1996, p. 45). The legal standard of likelihood of confusion corresponds to the foundational doctrine of the Lanham Act. Although the recent enactment of the dilution statute has shifted the scope of federal trademark law toward more intellectual property-type rights (Long, 2006), the Lanham Act initially intended to provide manufacturers with incentives to produce and sell high quality goods (Burgunder, 1997). The Lanham Act was arguably enacted to protect general consumers rather than owners (Kahn, 2004).

The concept of likelihood of confusion is predicated on a notion that the schematic linkage between a trademark and its goods or services is the essential value of the mark (Cho \& Moorman, 2014). This psychological connection is presumed to facilitate consumers' repeated purchases of products based on their positive prior consumption experience. Therefore, if this association is disrupted by a deceptively similar mark, it would devalue the core mechanism of the trademark as a facilitating vehicle of information processing and consumer confusion would likely ensue (Manta, 2007).

To examine the likelihood of confusion, almost all federal circuits have developed unique multifactor tests (Manta, 2007). One of the most widely known tests is the one developed by the Second Circuit in Polaroidv. Polarad Electronics (1961), which consists of eight factors:

1. strength of plaintiff's mark

2. the degree of similarity between the two marks

3 . the proximity of the products

4. the likelihood that the prior owner will bridge the gap

5. actual confusion

6. the reciprocal of defendant's good faith in adopting its own mark

7. the quality of defendant's product

8. the sophistication of the buyers. 
In general, no single factor can sufficiently establish likelihood of confusion (McCarthy, 2004).

\section{Trademark Dilution}

The scope of federal trademark law has been significantly expanded last two decades (Port, 2000; Thurmon, 2009). Such expansion was highlighted by the congressional enactment of the Trademark Dilution Act of 1995 and the Trademark Dilution Revision Act of 2006. Since the statute is arguably plaintiff-friendly (Edgecombe, 2002) and its underpinning rationale is a remarkable departure from the traditional notion of infringement theory, commentators have criticized multiple aspects of the law (e.g., vague concept of trademark dilution as a legal cause of action; Magliocca, 2001), statutory scheme that one-sidedly supports enforcement activities of powerful owners (Grinvald, 2011), inherent conceptual ambiguity between infringement and dilution (McCabe, 2000; Shanti, 2001), unsubstantiated presumption of mental connection in dilution theory (McCarthy, 2004), restriction of free expression (Curan, 2004; Lemley, 1999), and anticompetitive effects (Bradford, 2008).

The rationale behind the dilution law would not be in accordance with the traditional theory of infringement. Scholars have asserted that the public policy of traditional trademark jurisprudence is firmly centered on the protection of general public. Lemley (1999) argued that the Lanham Act did not intend to help trademark owners maximize profits at the expense of general consumers' welfare. Indeed, the legislative history of the Act indicates that Congress did not intend to create de facto intellectual property rights for trademark owners except to the extent that might be necessary to prevent deceptive use of marks (Kahn, 2004). The traditional infringement theory endorses trademarks not more than source identifiers. They are designed to facilitate repeated purchase of products that have delivered positive prior consumption experience. Since the Act intends to create incentives for sellers to produce superior products, the core provisions of the Act such as 15 U.S.C. $\S$ 1114(1)(a) and $\S 1125(\mathrm{a})(1)$, do not provide the legal cause of action without proof of consumer confusion (Kahn, 2004).

In contrast, the Trademark Dilution Act of 1995 and the Trademark Dilution Revision Act of 2006 radically changed the traditional legal notion. The law states:

[T] he owner of a famous mark . . shall be entitled to an injunction against another person who ... commences use of a mark . . that is likely to cause dilution by blurring or . . . tarnishment of the famous mark, regardless of the presence or absence of actual or likely confusion, of competition, or of actual economic injury. (Trademark Dilution Act, 15 U.S.C. $§ 1125(c)(1), 2012$ )

Under the statute, a plaintiff who owns a famous trademark may enjoin another owner which is likely to "dilute" the unique value of the plaintiff's mark in terms of "blurring" or "tarnishment." The statute provides the definition of "blurring" and "tarnishment":

"[D]ilution by blurring" is association arising from the similarity between a mark or trade name and a famous mark that impairs the distinctiveness of the famous mark. ... "[D]ilution by tarnishment" is association arising from the 
similarity between a mark or trade name and a famous mark that harms the reputation of the famous mark. (Trademark Dilution Act, 15 U.S.C. $§ 1125(c)$ (2), 2012)

The given statutory language reflects a remarkable change of the rationale behind federal trademark law because the dilution claim does not require the evidence of harmful effect on general public (i.e., likelihood of confusion). As a result, dilution law primarily protects the mark owners' intellectual property rights associated with the schematic value of trademarks (i.e., brand associations), which has been consistently negated by the traditional infringement theory. Lemley (1999) criticized this radical change on the ground that the concept of brand schema is too speculative to be legally recognized and the harm allegedly inflicted by dilution (i.e., so-called "death by paper cuts") might hardly be substantiated in practice.

Trademark dilution is based on a theoretical basis that is considerably different from trademark infringement. The doctrinal foundation of infringement claim endorses owners' rights associated with their marks only to the extent that trademarks are the source identifiers facilitating consumers' information processing and lowering product search cost. If a seller produces and effectively advertises its superior goods or services, the trademark would simplify and expedite consumers' brand choice process by eliminating the need of exhaustive product search and piecemeal comparison of countless competing choices. Under this rationale, the seller may enjoin another company or individual from using a similar mark only if it can show the public harm (i.e., likelihood of confusion), which may disrupt such valuable mechanism.

In contrast, the theory of dilution originally stated that, "the preservation of the uniqueness of a trademark . . constitutes the only rational basis for its protection" (Schechter, 1927, p. 831). This statement represented a significant departure from the traditional notion of trademark protection (Vapnyar, 2003). Schechter (1927) proposed that a mark must be protected not because it designates a source of products or services but because it conveys psychological values that pertain to the mark during and after the consumption of goods or services. Hence, he suggested that the value protected under the law must be the cognitive establishments and schematic entities as a form of de facto intellectual property. Since Schechter's thesis created notable repercussions, twenty-five states had enacted some form of dilution statutes by 1995 when Congress eventually passed the Federal Trademark Dilution Act of 1995 (Vapnyar, 2003).

A widely debated issue regarding trademark dilution law was whether plaintiffs are required to show likelihood of dilution or actual dilution to establish a prima facie (Moseley v. v. V. Secret Catalogue, Inc., 2003). In Moseley v. V. Secret Catalogue, Inc. (2003), the U.S. Supreme Court ultimately decided that the legal standard for federal dilution claims is not likelihood but actual dilution. That is, the Moseley Court opined that plaintiffs must show the actual harm inflicted by defendants' practices rather than the likelihood of harm. In response to this judicial skepticism, Congress passed the Trademark Dilution Revision Act of 2006 that expressly articulated the likelihood of dilution as the burden of proof required under the law (Long, 2006). While the ambiguity involved with the evidentiary standard caused by the unclear statutory language has been textually resolved, there 
are still unsettled controversies about the relevant public policy and rationale of the law (Beebe, 2008; Curan, 2004, Lemley, 1999; McKenna, 2009; Shanti, 2001; Tushnet, 2008).

\section{Harm of Trademark Dilution}

One of the most critical issues in trademark jurisprudence concerns the ambiguous characteristics of the harm that allegedly arises from trademark dilution (Lemley, 1999; Long, 2006; McKenna, 2009; Shanti, 2001; Tushnet, 2008). Scholars have proposed various methodologies and conceptualizations to characterize the elusive concept of dilution and the nature of the harm (Anten, 2005; Bible, 1998; Bradford, 2008; Bunker, Stovall \& Cotter, 2004; Kaiser, 2005; Lee, 2004; Magid et al., 2006; Morrin \& Jacoby, 2000; Simonson, 1993). In his seminal article, Schechter (1927) articulated the harm caused by dilutive use of famous marks as, "the gradual whittling away or dispersion of the identity and hold upon the public mind of the mark or name by its use on non-competing goods" (p. 825). According to the exposition, dilution is the loss of a famous mark's distinctive psychological value in consumer minds because of other noncompeting yet similar marks that are likely to weaken the unique schematic properties of the mark. Given this working definition, the next inquiries would be (1) what would be the distinctive value of schematic properties associated with trademarks? and (2) whether dilutive use substantially harms such valuable psychological properties. Potential answers to these two inquiries will be addressed in the next sections.

\section{Brand Equity Theory}

The brand equity theory (Aaker, 1991; Kapferer, 1997; Keller, 1993) provides an answer for the first question. According to Aaker (1991), brand equity is "a set of assets and liabilities linked to a brand's name and symbol that adds to or subtract from the value provided by a product or service to a firm and/or that firm's customers" (p. 15). Further brand equity is an added or decreased value with which a given brand endows a product (Farquhar, 1989), meaning, a deferred future income mainly attributed to the brand knowledge. Likewise, brand equity is a consumer-oriented concept that elucidates what kind of intangible value dilution law intends to protect.

Keller (1993) expounded the structure and elements of brand knowledge that eventually constitutes consumer-based brand equity (Figure 1). According to his article, brand knowledge consists of cognitive, schematic, and attitudinal valences that compositely form psychological configurations of a brand. Brand knowledge does have financial value since well-identified brand knowledge would likely facilitate consumers' brand choice and enhance their positive consumption experience. For instance, adidas is able to set premium prices on its products because the well-known brand is respected and has distinctive images. The Trefoil logo of the company may carry an array of positive psychological connotations that likely attract a significant number of consumers who would not choose the products without the mark. Since adidas presumably knew that the trademark conveys such power- 
ful meaning that may not be compromised, it attempted to enjoin Herbalife from using the Tri-Leaf logo. By the same token, Nike brought the legal action against Nikepal even though the defendant by no means vies for the same product category.

Figure 1 shows that Keller's brand knowledge consists of two primary subdomains (i.e., brand awareness and brand image). Brand awareness is a variable underpinned by brand recall and recognition. Basically, the domain of brand awareness represents the degree to which consumers correctly remember and relate the brand to its product or service (Keller, 1993). On the other hand, brand image is a composite of three schematic and attitudinal constructs (i.e., attributes, benefits, and attitudes; Keller, 1993). Brand attributes are schematic beliefs attributed to the given brand. An attribute would be either product-related (e.g., "Nike sneakers are of state-of-art design") or nonproduct-related, such as user imagery (e.g., "Nike

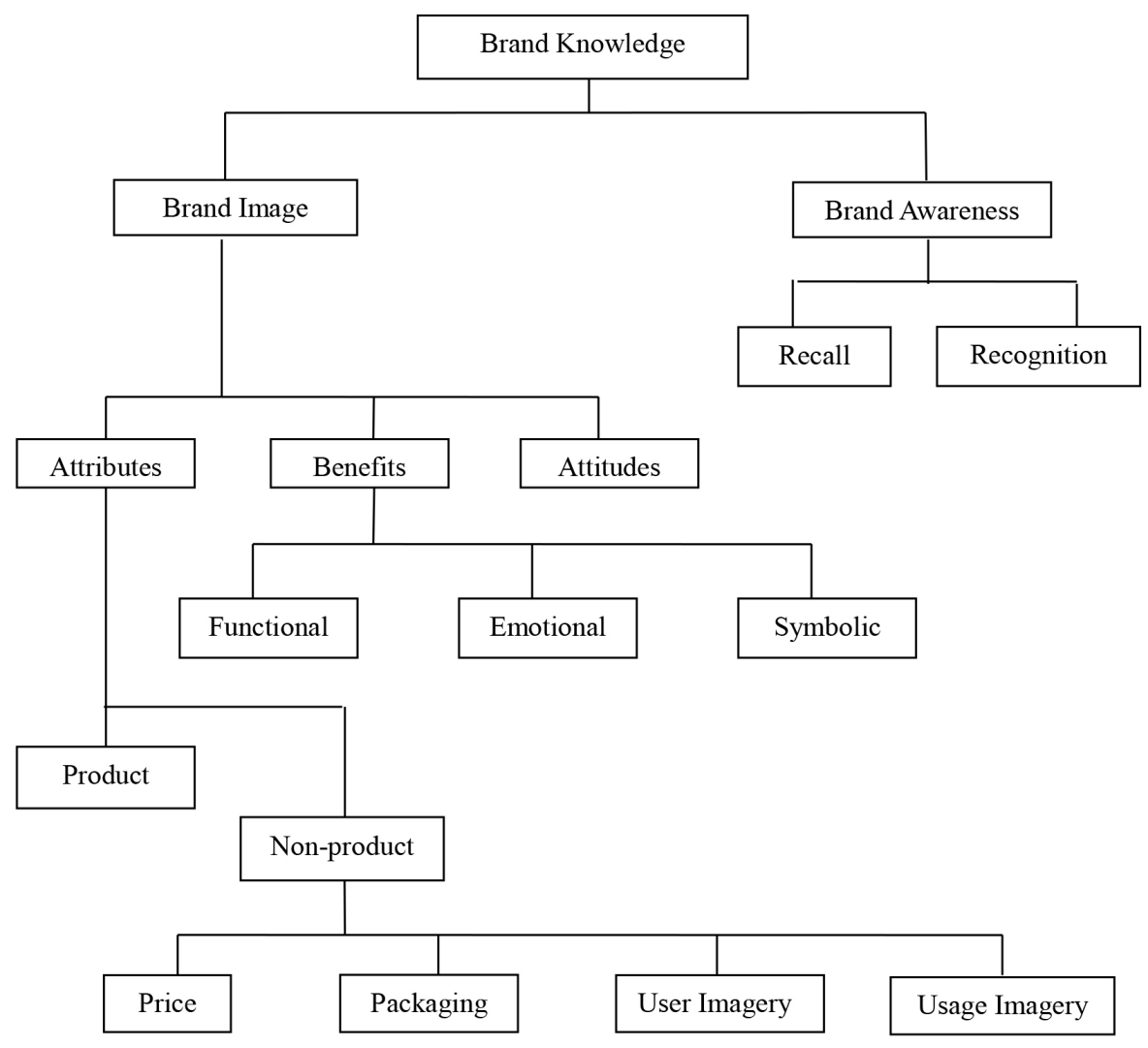

Figure 1 - Elements of brand knowledge (Keller, 1993). 
sneakers are mostly for gym-rats"). Benefits here indicate beliefs formed based on the consumers' cognitive evaluation of the utilitarian values associated with the brand or its products. They are in essence perceived advantages that consumers would expect from the brand and its products. It can be functional (e.g., "Nike sneakers are durable"), emotional (e.g., Nike sneakers are exciting), or symbolic (e.g., Nike sneakers symbolize successful athletes). Lastly, brand attitudes matter how positively consumers feel to a given brand or product represented by the brand. (e.g., I am in favor of Nike).

Although the psychological sphere of brand attributes encompasses both product-related and non-product-related schematic associations, this study focuses on brand personality that is a major non-product-related attribute because of two reasons. First, given the wide variety of product and service categories explored by this study, sport leagues and sponsors dealing with both tangible and intangible products, non-product-related brand attributes such as brand personality would be a better point of observation and analysis. It is almost impossible to construct a standardized measurement platform that encompasses such diverse product categories (e.g., credit card services versus sport event). A researcher has to make an inevitable analytic choice between generality and specificity (John, Naumann, \& Soto, 2008). Given the exploratory nature of the current investigation, the study focuses more on the issue of generality by limiting the point of observation.

\section{Brand Personality}

Brand personality is one of the most empirically substantiated constructs in brand research (Aaker, 1997; Cho \& Kang, 2012; Lee \& Cho, 2009; Lee \& Cho, 2012). Thus, it would provide more theoretically driven implications. Aaker (1997) developed Brand Personality Scale ("BPS" hereafter) based on Big-Five solution of human personality (McCrae \& Costa, 1985). Studies have repeatedly supported the validity of the BPS five factor solution in the context of sports (Cho \& Kang, 2012; Lee \& Cho, 2009; Lee \& Cho, 2012). In particular, Lee and Cho's study (2009) provides a useful measurement protocol for the current investigation. Their study examined match-up effects in sport sponsorship (Lynch \& Schuler, 1994). Rather than using the full scale five-factor solution, Lee and Cho measured and compared brand personalities of sports and sponsors in terms of one predominant dimension of each brand that was identified by a pilot study. Their study demonstrated that such piecemeal approach might be empirically acceptable in brand equity research.

In addition to brand personality, the current study includes attitude toward brand and perceived benefits that represent other domains of Keller's brand image. Lastly, perceived distinctiveness of given trademarks was analyzed as a criterion variable. While the distinctiveness of brand has been claimed as a core value of trademarks protected under dilution law (Magid et al., 2006; Schechter, 1927), no published study as of this writing has operationalized the concept. Given the paucity of relevant research, the current study attempted to assess the criterion validity (Thomas, Nelson, \& Silverman, 2011) of the ad hoc solution (i.e., whether the chosen variables conjointly capture the degree of distinctiveness). 


\section{Types of Dilution}

Trademark dilution is basically the reduction in brand equity (Magid et al., 2006; Simonson, 1993). Simonson (1993) conceptualized two different types of reduction in brand equity possibly caused by dilutive use of trademarks (i.e., typicality and evaluative dilution). Typicality dilution occurs when psychological associations between a senior mark and its products or services are weakened by one or more junior marks so that it becomes harder for consumers to activate and retrieve their memory associations that connect the senior mark to its typical product category (Simonson, 1993). Basically, this is dilution that diminishes the brand power in terms of the brand awareness in the Keller's model (Figure 1). Some brand extension studies (Aaker \& Keller, 1990; Batra, Lehmann, \& Singh, 1993; Boush \& Loken, 1991; Chakravarti, MacInnis, \& Nakamoto, 1990; Park, Milberg, \& Lawson, 1991) theoretically support this assertion. Based on brand extension research, proponents of dilution law have contended that one or more noncompeting junior marks would lead the diminution of brand power in terms of brand awareness (Magid et al., 2006; Morrin \& Jacoby, 2000; Simonson, 1993) because they may create cognitive dissonance and distraction.

While typically dilution is about the harmful effects on brand awareness (Simonson, 1993), evaluative dilution is related to brand image (Magid et al., 2006). Evaluative dilution basically refers to the harmful effects of one or more noncompeting junior marks on brand image of a famous senior mark. Some commentators have argued that brand image of a senior mark might be negatively influenced by a junior mark even if they do not compete within a market segment (Bradford, 2008; Morrin \& Jacoby, 2000; Simonson, 1993). When people perceive a pair of objects that are schematically well-matched (e.g., Ping golf glove), positive emotional valences would be formed (Bradford, 2008; Cho \& Kang, 2012). On the other hand, if they encounter a pair of dissonant objects (e.g., Ping grocery), negative valences would be established in terms of match-up hypothesis (Lynch \& Schuler, 1994). Thus, if consumers face a junior mark representing a product incongruent with a senior mark, such as Ping grocery, people may develop negative feelings. Likewise, in theory, the positive valences of brand attributes and benefits can be diluted by incongruent junior marks.

The next question is whether trademark dilution has substantially harmful effects on well-established psychological constellations of senior marks so that some judicial intervention is recommended. Simonson (1993) theoretically expounded the concept of trademark dilution and called for empirical inquiries that would prove negative effects of dilution caused by junior marks on well-established famous marks. Based on the Simonson's conceptualization, Magid et al. (2006) proposed an empirical setting designed to measure dilutive effects of junior marks on senior marks. The article proposed an instrument that measures brand recall, recognition, past purchase behavior, brand attitude, and demographics. The authors claimed that a set of pretest, posttest, and treatments where subjects are exposed to dilutive information may demonstrate the harmful effects of trademark dilution. Although the study provided the current investigation with a methodological protocol (i.e., 
quasi-experimental design), it did not present any empirical result. Moreover, their measurement scale mostly focused on brand awareness and failed to include two major prongs of brand image: brand attributes and benefits.

Morrin and Jacoby (2000) conducted the only published empirical study to examine the effects of dilution. Their study in essence examined whether junior marks have detrimental effects on brand awareness (i.e., recall and recognition). The study administered a quasi-experimental setting where subjects were exposed to dilutive advertisements for a set of famous marks such as Godiva, Hyatt, Heineken, Parker, Continental Airlines, and Avon. The authors found that subjects recognized product categories of the famous marks less successfully after they were exposed to corresponding junior marks. They also found that the speed of the recognition of typical product categories became slower by 123-164 ms when subjects were engaged with junior marks. In addition, the dilutive information negatively affected successful recall rates of some senior marks. Nevertheless, senior marks with exceptionally strong brand awareness (e.g., Continental Airlines) were largely immune to the dilution. Morrin and Jacoby's study partially supported the notion of Simonson's typicality dilution (i.e., harmful effects on brand awareness).

While Morrin and Jacoby's investigation revealed the evidence of dilution to some extent, their study exclusively focused on the typicality dilution that is only relevant to brand awareness. The study did not consider the impact on another major subdomain of Keller's brand equity (i.e., brand image; see Figure 1). Moreover, the result implied that a senior mark with an exceptionally high level of brand awareness would likely be immune to the alleged harm. This must have been particularly disconcerting and counter-intuitive to proponents of dilution law because the federal statute requires the proof of national fame as a threshold element for a dilution claim, meaning, the law only protects exceptionally famous marks (15 U.S.C. $§ 1125(c)(2)(A)$ (Trademark Dilution Act, 2012).

McKenna (2009) contended that Morrin and Jacoby's findings might not substantiate the harm allegedly caused by dilution. McKenna (2009) examined whether the relevant consumer behavior research supports the rationale of dilution theory. After an extensive literature review focusing on studies of brand extension, the author concluded that the empirical substance on point does not conclusively support the presumption of dilution law that noncompeting junior marks are harmful to senior marks. First, the author deduced that junior use of famous marks has no immediate harm. Thus, the harm at issue is either speculative or at least does not warrant a strong judicial remedy such as permanent injunction. McKenna also explicated that the proximity of product categories between junior and senior marks is a critical consideration but it has been largely disregarded by the rules of law. Assuming arguendo that junior use is harmful to a senior mark, the dilutive harm would occur only if the product category of the junior mark is extremely closely related to the senior mark. McKenna finally asserted that a junior mark can actually be beneficial to a senior mark since the junior use may enhance the existing brand knowledge of the senior mark by affirming the schematic configurations that connect the senior mark and its typical product category.

Tushnet (2008) also criticized Morrin and Jacoby's findings based on other findings of consumer psychology studies. Most of all, the article stated that Jacoby 
and Morrin's study lacked mundane realism since their experimental setting did not take into consideration contextual information that could have provided subjects with crucial cues. In fact, words without any contextual information are rare in our lives, except in a spelling bee. A linguist who worked as an expert witness in a number of trademark disputes stated,

I emphasized that meaning is flexible and determined by context. I used the word "green" as an example in the sentence, "Give me the green!" If this sentence is spoken by a speaker holding a bank teller at gun point, it means something quite different from what it would mean when an artist purchases oil paint at an art supply store. "The new mechanic was still a little green" we understand that "green" refers to inexperience, primarily from clues given by two other words in that sentence, "new" and "still." (Shuy, 2002, p. 101-102)

Since human beings commonly use contexts to disambiguate and figure out meanings of given words, it is reasonable to expect them to do the same thing with trademarks (Shuy, 2002).

In addition, Tushnet deduced that trademarks are low-frequency words that may not be negatively affected by noncompeting junior use. High-frequency words are those terms with a large number of existing contextual associations (e.g., "room"). If more associations are added to high-frequency words (e.g., junior use of mark), people may not easily activate their memory structure to elicit relevant schematic information attached to the given context (e.g., brand choice situation). In contrast, the schematic properties associated with low-frequency words (e.g., "corks") would be in fact enhanced by adding more contextual elements. Tushnet (2008) articulated that famous trademarks are not likely damaged by junior marks since research shows that they are still low-frequency words in our everyday language. Furthermore, even if a famous mark has become a high-frequency word somehow, junior use creates merely one more association to the term, which would have a negligible impact (Tushnet, 2008). In sum, while previous dilution research has provided valuable conceptual frameworks and methodological platforms, most of them were either theoretical expositions without any empirical result (Bradford, 2008; Magid et al., 2006; Shanti, 2001; Simonson, 1993) or disregarded a major domain of brand equity (Morrin \& Jacoby, 2000).

Given the controversies centered on the dilution law and paucity of relevant empirical research, this study examined whether junior use of famous marks has harmful effects on brand equity of the senior marks in terms of brand image (i.e., brand attributes, benefits, and attitude). The study specifically focused on three constructs of brand image: brand personality, perceived benefits, and attitude (Aaker, 1991). It employed a quasi-experimental design. In light of the theoretical foundation, two research questions were formulated:

Question 1: Is an ad hoc scale to measure distinctiveness of sport-related trademarks in terms of brand personality, perceived benefits, and brand attitude empirically conceivable?

Question 2: Is junior use harmful to brand image of famous sport-related trademarks? 


\section{Methodology}

\section{Study 1: Developing an Ad Hoc Measurement Scale}

Instrumentation. An ad hoc instrument (Appendix 1) was constructed based on previous studies (Aaker, 1991; Aaker, 1997; Cho \& Kang, 2012; Keller, 1993; Lee \& Cho, 2009; Lee \& Cho, 2012) and feedbacks from a panel of three marketing experts. The instrument was designed to measure the previously mentioned variables (i.e., brand personality; Aaker, 1997; Cho \& Kang, 2012), brand attitude (Aaker, 1991), and perceived benefits (Keller, 1993). Table 1 shows the variables and corresponding items measured by the proposed scale.

Aaker (1997) conducted a psycho-lexical analysis (McCrae \& Costa, 1985) to extract an inventory of 15 traits that can comprehensively capture various descriptions of brand personality such as down-to-earth, honest, wholesome, cheerful, daring, spirited, imaginative, up-to-date, upper-class, charming, outdoorsy, tough, reliable, intelligent, and successful. Based on the Big-Five Human Personality theory developed by McCrae and Costa (1985), Aaker developed a five-factor solution, the BPS, in which the above-mentioned 15 traits are collapsed into five dimensions: sincerity, excitement, competence, sophistication, and ruggedness. Various empirical studies (Aaker, Benet-Martinez, \& Garolera, 2001; Cho \& Kang, 2012; John et al., 2008; Sweeney \& Brandon, 2006) supported the robustness of the Aaker's five-factor solution.

Table 1 Variables, Questions, and Measurement Items

\begin{tabular}{|c|c|c|}
\hline Variables & Questions & Measurement Items \\
\hline Attributes & $\begin{array}{l}\text { How would you rate each of the } \\
\text { following brands based on given } \\
\text { adjectives? }(1=\text { Not descriptive; } 7 \\
\text { = Very descriptive })\end{array}$ & BPS adjectives \\
\hline Attitudes & $\begin{array}{l}\text { Rate your favorability of brands } \\
(1=\text { Not like at all; } 7=\text { Really } \\
\text { Like })\end{array}$ & Favorability score \\
\hline \multirow[t]{2}{*}{ Benefits } & \multirow{2}{*}{$\begin{array}{l}\text { How would you rate the given } \\
\text { statements with respect to the } \\
\text { brands/events? }\end{array}$} & $\begin{array}{l}\text { This brand provides some advan- } \\
\text { tages to its users (sponsors) }\end{array}$ \\
\hline & & $\begin{array}{l}\text { This event provides some type of } \\
\text { benefits to its fans (sport events) }\end{array}$ \\
\hline \multirow[t]{2}{*}{$\begin{array}{l}\text { Distinctive- } \\
\text { ness }\end{array}$} & \multirow{2}{*}{$\begin{array}{l}\text { How would you rate the given } \\
\text { statements with respect to the } \\
\text { brands/events? }\end{array}$} & $\begin{array}{l}\text { Overall, this brand has "distinc- } \\
\text { tive" value (sponsors) }\end{array}$ \\
\hline & & $\begin{array}{l}\text { Overall, this sport event has } \\
\text { "distinctive" brand value (sport } \\
\text { events) }\end{array}$ \\
\hline
\end{tabular}


Sponsorship studies examined the applicability of the BPS in the context of sport sponsorship (Cho \& Kang, 2012; Lee \& Cho, 2009; Lee \& Cho, 2012). Lee and Cho (2009) conducted an investigation where brand personalities of sport leagues and sponsors were matched. The researchers measured and compared brand personalities of sports and sponsors in terms of one predominant BPS dimension rather than the entire five-factor solution. They initially conducted a pilot study where the most representative BPS dimension for each sport league and sponsor was identified based on total dimensional factor scores. The aggregation of dimensional scores has been used in brand attribute research (Cho \& Kang, 2012; Musante, Milne, \& McDonald, 1999) to estimate schematic prominence of brand configurations. Lee and Cho (2009) demonstrated that their piecemeal application of the BPS is empirically acceptable.

Cho and Kang (2012) conducted another sponsorship matching study to scrutinize the psychometrical comparability of the BPS solution with respect to sports and sponsors. The investigation also employed a pilot study that assessed the structural coherence of the BPS dimensions with respect to various sport entities and sponsors. Based on the pilot study, researchers chose two pairs of sports and sponsors for the comparability analysis (i.e., MLB-Nike and PGA-Benz). Their research showed that, in sponsorship matching, selective use of a predominant BPS dimension might be more reliable than using all five BPS dimensions.

Given the previous studies, five major sponsors of sport events (Mastercard, Marlboro, Nike, Budweiser, and Mercedes Benz) and five sport leagues (PGA, NHL, NFL, NBA, and MLB) were selected as target brands. The sponsors and sport leagues were chosen based on two criteria: (1) predominant BPS dimensions determined by total factor scores; and (2) structural coherence [i.e., factor loadings $(\lambda)$ and disturbances $(\Theta)$ ] of the respective BPS dimensions, estimated in the previous study (Cho \& Kang, 2012). Thus, sport events and sponsors were not paired in the ad hoc solution based on sponsorship or other affiliations, but paired in terms of the commonality of predominant BPS dimensions.

Aaker (1991) and Keller (1993) designated brand attitude and perceived benefits as additional components of brand equity. Accordingly, the ad hoc scale was designed to measure the favorability of chosen brands and perceived benefits. Attitude research in consumer psychology has stemmed from two perspectives (i.e., unidimensional and tripartite approaches; MacKenzie, Lutz, \& Belch, 1986). According to the unidimensional approach, attitude can be defined as "a learned predisposition to respond in a consistently favorable manner with respect to a given object" (Fishbein \& Ajzen, 1975, p 6). This perspective expounds that attitude reflects a person's feelings toward an object and it can be measured on an evaluative continuum ranging from favorable to unfavorable. On the other hand, the tripartite approach predicates on a notion that attitude consists of three components: affect, cognition, and conation. In spite of such inclusiveness, the approach has been criticized for lack of empirical coherence mainly due to the distinctive nature of the three constructs (Lutz, 1981). Thus, the ad hoc instrument for the current study used one measurement item to capture the sphere of brand attitude ("Rate your favorability of brands"). By the same token, another item was included in the questionnaire to measure the domain of perceived benefits ("This brand provides some advantages to its users" and "This event provides some type of benefits to its fans"). Lastly, two questions were included to measure the distinctiveness of 
brands and their products. Following marketing experts' suggestion, the overall distinctiveness of brand was used to check the criterion validity of the instrument.

Data Collection. Four hundred and fifty-one undergraduate and graduate students enrolled in sport management courses at a medium size Midwestern university were recruited for Study 1 during the academic year of 2011-2012. Subjects were awarded an extra course credit for their participation in the study. After the researchers briefly explained the purpose of the study as an investigation of how people perceive famous sport-related marks, a questionnaire was distributed. Initially, respondents were given ten minutes to complete the survey. Additional five minutes were allowed if requested. Subjects were asked to complete the survey without any missing value. Given the exploratory nature of this research, use of student sample might be acceptable (Cook \& Campbell, 1979) in spite of its inherent shortcomings, e.g., lack of generalizability. Social psychologists have supported such use of homogeneous sample such as sport management or related majors, to minimize the variability of constructs presented by an ad hoc measurement solution and to address threats to statistical conclusions in quasiexperimental settings (Calder, Phillips, \& Tybout, 1981; Cook \& Campbell, 1979).

Data Analysis. A set of Confirmatory Factor Analyses ("CFA" hereafter) was conducted to examine the instrumental validity of the scale by using LISREL 8.80. Since the ad hoc instrument had two one-item latent variables (i.e., perceived benefits and brand attitude), Cronbac's alphas were estimated instead of the Average Variance Extracted (Fornell \& Larker, 1981). A series of regression analyses were undertaken to check the criterion validity of the scale (i.e., whether the scale successfully captures the psychological domain of the distinctiveness of the chosen trademarks). SPSS 21.0 was used for the regression analyses.

\section{Study 2}

By employing the ad hoc measurement scale, Study 2 examined whether dilution has harmful impacts on brand image of sport trademarks. Sixty two subjects were recruited from two sport management classes for Study 2 during the academic year of 2012-2013. All participants were awarded three extra course credits for their participation in the entire process of Study 2.

First, subjects were asked to complete a pretest to measure their preexisting perception of brand personality, attitude, and benefits associated with the selected ten trademarks. The survey was administered electronically and respondents had unlimited access to the questionnaire during a week-long data collection period. Second, subjects participated in an online discussion session where they were asked to make comments on hypothetical trademark dilution. This treatment session consisted of ten sets of stimuli where the selected ten sport-related trademarks are used by noncompeting junior users for irrelevant goods or services. The hypothetical stimuli were designed to make respondents cognitively engage in the situational information processing that possibly affect their perception of the brand image of the famous senior trademarks. Each stimulus was followed by three open-ended questions. For instance, one of the stimuli sets states 
Larry Gorthland is a hair stylist who owns a small but very successful beauty salon in Toledo, OH. His shop is well known for its newfangled New York style perm. This month Larry initiates a membership campaign, "Perm-byGorthland Assurance." Under the program, customers would enjoy various after-care package deals when they have perm at Larry's beauty salon and purchase the membership. One of the package deals under the membership program is "PGA First Class."

Q1: Do you think Larry's membership plan, "PGA First Class" may create confusion in minds of sport fans? If yes, why? If not, why?

Q2: How would you think the name of the new membership program? Is it acceptable? If yes, why? If not, why?

Q3: You are now buying either a pair of pants with the PGA logo or other sport events. Do you think that your brand choice would be affected by what Larry does?

Participants were asked to complete all 10 stimuli sets within a week-long treatment period. One week cooling period was given to subjects before a posttest was undertaken. The cooling period was administered to minimize possible bias from the treatment stimuli on the ground that brand equity is presumably stored and activated in the system of long-term memory association and retrieval (Ratcliff, 1978). Paired samples $t$ tests were used to estimate statistical differences between the pretest and the posttest with respect to the senior marks in terms of their total brand equity scores. The total brand equity score of each mark was calculated as the sum of all three brand image scores rated by respondents (i.e., total brand equity score $=$ brand personality score + attitude score + perceived benefits score). In addition, another set of paired $t$ tests were conducted to test the score change between the pretest and the posttest at the level of individual variables.

\section{Results}

\section{Study 1}

A data set was prepared for the CFAs after eliminating responses with any missing value. The final sample size became 419 where the mean age was 20.98 and $60.1 \%$ of the subjects were sport-related majors. The instrumental validity of the proposed scale was examined with respect to the selected trademarks $(N=419)$. Goodness-of-fit indices for the CFAs indicate that the scale is statistically reliable $\left(\chi^{2}=19.23-99.11 ;\right.$ RMSEA $=0.06-0.11 ; \mathrm{NFI}=0.95-0.98 ; \mathrm{NNFI}=0.92-0.98 ; \mathrm{CFI}$ $=0.96-0.98)$. In addition to the CFAs, Cronbach's $\alpha$ for the scale with respect to each targeted trademark shows that the scale is reliable (Cronbach's $\alpha$ : Budweiser $=0.836 ; \mathrm{NBA}=0.852 ; \mathrm{Nike}=0.829 ; \mathrm{NHL}=0.847 ;$ MasterCard $=0.712 ; \mathrm{PGA}=$ 0.793; Marlboro = 0.725; NFL =0.747; Mercedes Benz $=0.786 ;$ MLB $=0.826$ ). Table 2 reports the result of the CFA. 
Table 2 Confirmatory Factor Analysis (Cut-Off Criteria)

\begin{tabular}{lccccc}
\hline Trademark & $\boldsymbol{\chi}^{\mathbf{2}}$ & RMSEA $(\mathbf{0 . 1}>)$ & NFI $(\mathbf{0 . 9 5}<)$ & NNFI $(\mathbf{0 . 9}<)$ & CFI $(\mathbf{0 . 9}<)$ \\
\hline MASTER CARD & 19.23 & 0.06 & 0.96 & 0.98 & 0.98 \\
MARLBORO & 24.84 & 0.08 & 0.96 & 0.95 & 0.97 \\
NIKE & 60.83 & 0.08 & 0.96 & 0.96 & 0.97 \\
BUDWEISER & 67.50 & 0.08 & 0.96 & 0.96 & 0.97 \\
BENZ & 26.31 & 0.06 & 0.98 & 0.98 & 0.99 \\
PGA & 29.33 & 0.09 & 0.97 & 0.95 & 0.98 \\
NHL & 99.11 & 0.11 & 0.95 & 0.93 & 0.96 \\
NFL & 35.58 & 0.11 & 0.95 & 0.92 & 0.96 \\
NBA & 79.92 & 0.09 & 0.96 & 0.95 & 0.97 \\
MLB & 66.18 & 0.11 & 0.95 & 0.94 & 0.96 \\
\hline
\end{tabular}

* Cut-off criterion for $\chi^{2}$ is not provided since there is no consensus and it is almost always significant when sample size is more than 200 (Kenny, 2013). $p<0.05$.

A series of multiple regression analyses examined the criterion validity of the solution (Dependent Variable = overall distinctiveness; Independent Variables $=$ brand personality, attitude, and perceived benefits). The result verifies that the independent variables (IVs) are significant predictors of the dependent variable (DV) with respect to all marks. Meaning, the brand equity variables successfully captured the psychological domain of the criterion variable, the distinctiveness of trademarks $\left(R^{2}=.23-0.42 ; F=59.49-24.47\right.$; sig. $\left.=0.001\right)$.

\section{Study 2}

Fifty six subjects completed Study 2. Paired samples $t$ test was undertaken to examine whether the treatment influenced the brand equity of the senior marks $(N$ =56). Table 3 reports the results. A majority of the marks shows significant change in brand equity between the pretest and posttest [i.e., MasterCard $(t=-3.385$; sig. $=0.01)$, Mercedes Benz $(t=-3.821$; sig. $=0.01)$, PGA $(t=-5.535 ;$ sig. $=0.01)$, NHL $(t=-3.361$; sig. $=0.01)$, NFL $(t=-2.217$; sig. $=0.03)$, NBA $(t=-5.787$; sig. $=0.01)$, MLB $(t=-3.766$; sig. $=0.01)]$, while three trademarks does not reveal statistically significant change [i.e., Marlboro $(t=1.166$; $\operatorname{sig} .=0.249)$, Nike $(t=$ -0.244 sig. $=0.808)$, and Budweiser $(t=-0.746$; sig. $=0.459)]$. Interestingly, most of the posttest scores are increased rather than decreased. Only Marlboro showed the posttest score lower than the pretest (pretest $=14.61$; posttest $=13.86$ ), but without statistical significance $(t=1.166$; sig. $=0.249)$.

\section{Discussion}

This investigation is another effort to substantiate the harmful effects of trademark dilution, specifically focusing on the schematic properties of brand image. It employed a theory-driven ad hoc measurement platform. A quasi-experimental 
Table 3 Paired Samples $t$-test: Brand Equity Scores (Pre- and Posttest)

\begin{tabular}{lcccc}
\hline & \multicolumn{2}{c}{ Brand equity mean score } & & \\
\cline { 2 - 3 } Trademark & Pretest & Posttest & $\boldsymbol{t}$ & Sig. \\
\hline MASTER CARD & 18.80 & 20.34 & -3.385 & 0.001 \\
MARLBORO & 14.61 & 13.86 & 1.166 & 0.249 \\
NIKE & 38.20 & 38.32 & -0.244 & 0.808 \\
BUDWEISER & 28.63 & 29.07 & -0.746 & 0.459 \\
BENZ & 29.04 & 30.55 & -3.821 & 0.001 \\
PGA & 19.16 & 20.88 & -5.535 & 0.001 \\
NHL & 27.11 & 29.29 & -3.361 & 0.001 \\
NFL & 24.23 & 24.98 & -2.217 & 0.031 \\
NBA & 27.13 & 30.25 & -5.787 & 0.001 \\
MLB & 25.64 & 27.59 & -3.766 & 0.001 \\
\hline
\end{tabular}

procedure was designed to extrapolate any relationship between dilutive information and the alleged harm. Given the statistical robustness of the proposed scale, the study recommends such schematic scaling solution in other trademark inquiries where psychometrical measurement is a central concern. More importantly, this study highlights why more empirical research is called for the substantiation of dilution theory. Although Morrin and Jacoby's (2000) investigation discovered harmful effects of dilution on brand awareness to some degree, they did not address anything related to brand image, the other major domain of brand equity (Aaker, 1991; Aaker, 1997; Keller, 1993). In addition, the current study disproves the notion of evaluative dilution (i.e., the harmful effects of dilution on brand image; Simonson, 1993). The $t$ test suggests that the schematic brand image of the senior marks was seemingly strengthened rather than weakened (Table 3). Such disconcerting result is actually in accordance with a theoretical argument that dilution might not be substantially harmful or, at minimum, the nature of the harm is not of a kind that a judicial intervention is necessary (McKenna, 2009; Tushnet, 2008).

Some theories indicate that when people encounter a pair of disparate objects, such intriguing disparity may form a cognitive arousal that makes them more attentive and engaged (McKenna, 2009; Tushnet, 2008). Along with McKenna's (2009) assertion, this investigation reveals that junior use might not have substantially harmful effects on senior marks' brand image, at least immediately. Rather, the $t$ test suggests that some junior use would even be beneficial to senior marks. According to Tushnet (2008), even if they are really famous, trademarks are basically lowfrequency words that would be enhanced schematically rather than weakened by adding a small number of intriguing associations (i.e., junior use). The findings of this study specifically support that non-product-related brand attributes, such as brand personality, might be more configurated by junior use since such cognitive disparity would activate some ancillary associations that might not be triggered 
otherwise. It is theoretically plausible on the ground that the constellations of non-product-related attributes are less likely configurated than other valences such as attitude and perceived benefits (Aaker 1997) so that they would be more interactive with the given stimuli. For instance, if a consumer sees Nikepal syringe, such schematic incongruity is likely to stimulate and activate the associative nodes of Nike stored in the person's memory retrieval system. It then likely elicits an affirmation of the existing constellations connected to Nike, such as typical users, high-profile spokespersons, etc. As a result, it would enhance rather than damage the brand schemata of Nike.

While the online treatment sessions were designed to make respondents cognitively engaged with dilutive information rather than collect primary data for a content analysis, some comments are notable in this context.

"[Junior use] will boost the brand choice [of the senior mark] due to heavily seeing the word [more] often."

"If I had both credit line[s] open more than likely I will use the MasterCard before the Visa just because of the acknowledgment the word MASTER captured in my mind."

"My [brand] choice will be affected by [the junior use] mentally and will have my mind set on [MasterCard]."

"I do not think that as a restaurant owner my brand choice of alcohol would be influenced by a home builders company but hearing their name would make me think of Budweiser."

"When deciding whether to buy a sedan or not the fact the [junior user] compares themselves to Mercedes Benz can only help Mercedes and make consumers want to buy one more since people think so highly of them."

In addition, a number of comments collected from treatment sessions indicated that junior use would not likely have impact on brand choice. Basically, many respondents stated that noncompeting junior use might have no considerable impact without likelihood of confusion. Their reasoning is clearly based on infringement theory rather than dilution.

"I don't think picking a hooded sweatshirt selection would be affected by in any way by the [junior mark]. I believe this just because I am pretty sure that ... these companies have totally different [products]."

"I don't think that picking a lighter would be affected by the prep school's medal."

"I can't see them getting confused or thinking they're related. When choosing to buy a pair of golf pants or anything else with a PGA logo on it, I can't imagine anyone's decision being [affected] by what [junior user] does." 
"People are going to buy the jersey of the player and team they want, they aren't going to think about real estate firms or other companies that have nothing to do with it."

"If I had both a Visa and MasterCard in my wallet, the name of some other brand would not affect my decision at all when it comes down to which card I would make a purchase with. The playing cards name is completely independent from actually buying something with a type of credit card."

In sum, although junior use may slow down the memory retrieval process for senior marks in milliseconds (Morrin \& Jacoby, 2000), it may not substantially harm their brand image. At minimum, it can be inferred from this study and previous research that two domains of brand equity (i.e., brand awareness and brand image) would process dilutive information by using different information processing (Fitzsimons, et al., 2002). Further empirical research may provide more explanations why they react to such stimuli differently.

There are legal paradigms mainly predicated on social science because their doctrinal foundations are significantly dependent on empirical findings. The relationship between antitrust law and economics might be a quintessential example. Similarly, the core rationale of trademark law is firmly based on empirical substances of consumer behavior research. One noteworthy trend is that while a majority of modern economics theories has brought more deregulation of traditional antitrust doctrines, consumer psychology in most cases has been in support of more stringent enforcement and expansion of protective theories such as dilution (Tushnet, 2008). As the rationale of dilution theory is mainly about the psychometrically measurable domain such as brand equity, further empirical investigations similar to this investigation are recommended. When the empirical substances provide more coherent information, it will eventually disprove or substantiate the harmful effects of trademark dilution.

\section{Future Studies}

Some future studies are recommended. This investigation exclusively addressed dilution by blurring. More inquiries on tarnishment theory are called for. Commentators have pointed out that the cause of action for tarnishment under the dilution law directly collides with the First Amendment commercial speech doctrine (McKenna, 2009; Tushnet, 2008). Given the possibility of inhibitive effects on free expression (Curan, 2004), a doctrinal scrutiny of tarnishment theory must be undertaken in light of the constitutional law. Empirical examinations are likely to reveal more insightful information (e.g., an outcome determinant analysis comparing blurring and tarnishment cases in relation to the free speech doctrine, a behavioral examination of the chilling effect caused by dilution law, etc.). A thorough investigation of the jurisprudential crossroad between dilution law and the First Amendment would construct a more coherent doctrinal paradigm on point.

People's cognitive information processing is critically determined by available contextual information. A follow-up investigation may introduce more experimental 
controls and manipulations to the inquiry (e.g., dilutive information coupled with product-category information, perceptive cues, preexisting brand loyalty, and purchase intention). During the treatment session, one comment echoed Tushnet's (2008) assertion that noncompeting junior use may not have significantly detrimental effects on senior marks because contextual information would likely dictate most of brand choice situations: "People eating and drinking in a restaurant aren't going to care what some building company may or may not be called, they're only going to care what beer you have if they want one."

A study may test whether the requirement of national fame under the statute is in accordance with relevant consumer psychology theories and empirical findings. Morrin and Jacoby's (2000) study revealed that trademarks with exceptionally strong brand awareness would likely be immune to the dilutive harm of junior use. Given the inconsistency between the empirical finding and the rules of law, more research needs to be done to scrutinize the impact of strong brand awareness on the information processing of dilution. The online treatment sessions present relevant comments:

"I do not think that my brand choice would be affected by [Nikepal] since I am [much] more familiar with Nike."

"If a popular brand comes out with a new shoe then it will sell no matter what. Nikepal would have not affected on what others do. Especially in today's age where popularity and becoming distinct is very relevant in how things are bought."

"I do not think my brand choice would be affected by what Nikepal does here because Nike is my favorite brand and I know what is affiliated with the Nike brand as far as buying Nike sneakers, and I would be positive and confident in my purchase selections regardless of what Nikepal does."

\section{Research Limitations}

The current investigation has an array of limitations. First, the treatment sessions lack mundane realism (Thomas et al., 2011). A real world situation where consumers interact with dilutive information might be considerably different from the study settings, particularly, in terms of contextual cues. In reality, the dilutive information might not likely be anecdotal stories of junior use but ad materials, tangible or intangible product, etc. Second, this study by no means suggests any definite causality between junior use and changed brand image scores since the protocol did not control a number of extraneous variables such as major events during the treatment period that would have affected subjects' perception of given trademarks. Unless a true experimental design (i.e., Solomon-Four Group Experimentation; Thomas et al., 2011) is implemented in conjunction with more careful control of extraneous variables, any causal relationship may not be inferable from this type of quasi-experimental inquiry. Third, experimental artifacts such as demand characteristics might have been present if subjects could realize the purpose of the study (Magid et al., 2006). Fourth, the ad hoc solution used in this study did not cover some schematic entities of Keller's (1993) brand image (e.g., product-related attributes, additional BPS traits, etc.). Fifth, this study has little generalizability 
since it used a student sample primarily consisted of sport-related majors and only focused on a small number of sport trademarks.

\section{Conclusion}

\section{Implications}

This study presented several practical implications. First, parties in trademark disputes may adopt the methodological platform implemented by this study to obtain relevant evidence. In light of this study, plaintiffs in dilution cases would attempt to highlight likelihood of typicality dilution (i.e., dilution of brand awareness), while defendants may try to emphasize lack of evaluative dilution (i.e., dilution of brand image). Given the discursive empirical results, however, such empirical evidence must be produced with caution because it may become a double-edged sword. Second, this investigation and its future progenies may provide policy makers with more helpful information to clarify the jurisprudence of dilution statute. If dilution theory is not empirically sustainable, the law must be repealed under the commercial speech doctrine (Tushnet, 2008). Third, the ad hoc scale employed in this study demonstrated that sport events and sponsors can be psychometrically matched based on a standardized measurement platform (Cho \& Kang, 2012). Brand managers would be able to use the approach for sponsorship matching process and evaluation (Lee \& Cho, 2009), brand extension (Aaker \& Keller, 1990), as well as strategic alliance among others.

\section{Acknowledgments}

The author would like to thank Dr. Jacquelyn Cuneen for providing various inputs to this investigation.

\section{References}

Aaker, D.A. (1991). Managing brand equity: Capitalizing on the value of a brand name. New York, NY: The Free Press.

Aaker, D.A., \& Keller, K.L. (1990). Consumer evaluations of brand extensions. Journal of Marketing, 54(1), 27-41. doi:10.2307/1252171

Aaker, J.L. (1997). Dimensions of brand personality. JMR, Journal of Marketing Research, 34(3), 347-356. doi:10.2307/3151897

Aaker, J.L., Benet-Martinez, V., \& Garolera, J. (2001). Consumption symbols as carriers of Culture: A study of Japanese and Spanish brand personality constructs. Journal of Personality and Social Psychology, 81(3), 492-508. doi:10.1037/0022-3514.81.3.492 adidas et al. v. Herbal Life International, Inc. (D.C. Or. complaint filed June 12, 2009) (No. CV 09-661-MO).

adidas et al. v. Herbalife, Inc., 2010 U.S. Dist. LEXIS 13327 (D. Ore., Feb 10, 2010). adidas et al. v. Herbalife, Inc., 2011 U.S. Dist. LEXIS 69858 (D. Ore., May 18, 2012).

Amoco Production Co. v. Gambell, 480 U.S. 531 (1987).

Anten, T. (2005). In defense of trademark dilution surveys: A post-Moseley proposal. Columbia Journal of Law and Social Problems, 39, 1-45.

Batra, R., Lehmann, D.R., \& Singh, D. (1993). The brand personality component of brand goodwill: Some antecedents and consequences. In D.A. Aaker \& A.L. Biel (Eds.), 
Brand Equity \& Advertising (pp. 83-96). Hillsdale, NJ: Lawrence Erlbaum Associates, Publishers.

Beebe, B. (2008). The continuing debacle of U.S. antidilution law: Evidence from the first year of Trademark Dilution Revision Act case law. Santa Clara Computer and HighTechnology Law Journal, 24, 449-467.

Beerline, J.F. (2008). Anti-dilution law, new and improved: The Trademark Dilution Revision Act of 2006. Berkeley Technology Law Journal, 23, 511-535.

Beverland, M.B. (2005). Creating value for channel partners: The Cervena case. Journal of Business and Industrial Marketing, 20(3), 127-135. doi:10.1108/08858620510592740

Beverland, M. B., Napoli, J., \& Yakimkova. (2007). Branding the business marketing offer: Exploring brand attributes in business markets. Journal of Business and Industrial Marketing, 22(6), 394-399. doi:10.1108/08858620710780154

Bible, P.M. (1998). Defining and quantifying dilution under the Federal Trademark Dilution Act of 1995: Using survey evidence to show actual dilution. University of Colorado Law Review, 70, 295-340.

Boush, D.M., \& Loken, B. (1991). A process-tracing study of brand extension evaluation. JMR, Journal of Marketing Research, 28(1), 16-28. doi:10.2307/3172723

Bradford, L.R. (2008). Emotion, dilution, and the trademark consumer. Berkeley Technology Law Journal, 23, 1227-1298.

Brogan, S.H. (1996). Who are these "Colts?": The likelihood of confusion, consumer survey evidence and trademark abandonment in Indianapolis Colts, Inc. v. Metropolitan Baltimore Football Club, LTD. Marquette Sports Law Review, 7(1), 39-75.

Bunker, M.D., Stovall, J.G., \& Cotter, P.R. (2004). Proving dilution: Survey evidence in trademark dilution actions. University of Baltimore Intellectual Property Law Journal, $13,37-55$.

Burgunder, L.B. (1997). Trademark protection of product characteristics: A predictive model. Journal of Public Policy \& Marketing, 16(2), 277-288.

Calder, B.J., Phillips, L.W., \& Tybout, A.M. (1981). Designing research for application. The Journal of Consumer Research, 8(2), 197-207. doi:10.1086/208856

Chakravarti, D., MacInnis, D.J., \& Nakamoto, K. (1990). Product category perceptions, elaborative processing and brand name extension strategies. Advances in Consumer Research. Association for Consumer Research (U. S.), 17(1), 910-916.

Cho, S., \& Kang, J. (2012). Psychometric comparability of Brand Personality Scale: Assessing brand personality matching between sports and corporate sponsors by using Congenerity Test. International Journal of Sports Marketing \& Sponsorship, 13(4), 295-312.

Cho, S., \& Moorman, A. (2014). An examination of the psychometrical comparability of survey evidence in sport trademark litigation. Journal of Legal Aspects of Sport, 24(1), 3-23. doi:10.1123/jlas.2013-0010

Cook, T.D., \& Campbell, D.T. (1979). Quasi-experimentation: Design and analysis issues for field settings. Boston, MA: Houghton Mifflin Company.

Cretu, A.E., \& Brodie, R.J. (2007). The influence of brand image and company reputation where manufacturers market to small firms: A customer value perspective. Industrial Marketing Management, 36(2), 230-240. doi:10.1016/j.indmarman.2005.08.013

Curan, P.D. (2004). Diluting the commercial speech doctrine: "Noncommercial Use" and the Federal Trademark Dilution Act. The University of Chicago Law Review. University of Chicago. Law School, 71, 1077-1108.

Dyer, D., Dalzell, F., \& Olegario, R. (2004). Rising tide: lessons from 165 years at Proctor \& Gamble. Boston, MA: Harvard Business School Press.

eBay, Inc. v. Mercexchange, LLC., 547 U.S. 388 (2006).

Edgecombe, J.R. (2002). Off the mark: Bringing the Federal Trademark Dilution Act in line with established trademark law. Emory Law Journal, 51, 1247-1280.

Farquhar, P.H. (1989). Managing brand equity. Marketing Research, 1(3), 24-33. 
Fishbein, M., \& Ajzen, I. (1975). Belief, attitude, intention, and behavior: An introduction to theory and research. Reading, MA: Addison-Wesley.

Fitzsimons, G.J., Hutchinson, J.W., Williams, P., Alba, J.W., Chartrand, T.L., Huber, J., . . . Tavassoli, N.T. (2002). Non-conscious influence on consumer choice. Marketing Letters, 13, 269-279. doi:10.1023/A:1020313710388

Fornell, C., \& Larker, D.F. (1981). Evaluating structural equation models with unobservable variables and measurement error. JMR, Journal of Marketing Research, 18(1), 39-50. doi: $10.2307 / 3151312$

George, A. (2005). Brand rules: When branding lore meets trademark law. Journal of Brand Management, 13(3), 215-232. doi:10.1057/palgrave.bm.2540265

Grady, J., \& McKelvey, S. (2008). Trademark protection of school colors: Smack Apparel and Sinks decisions trigger color-ful legal debate for the collegiate licensing industry. Journal of Legal Aspects of Sport, 18(2), 207-242.

Grinvald, L.C. (2011). Shaming trademark bullies. Wisconsin Law Review, 2011, 625-689.

John, O.P., Naumann, L.P., \& Soto, C.J. (2008). Paradigm shift to the integrative Big-Five Trait taxonomy: History, measurement, and Conceptual Issues. In O.P. John, R.W. Robins, \& L.A. Pervin (Eds.), Handbook of personality: Theory and research (pp. 114-158). New York, NY: Guilford Press.

Kahn, M.A. (2004). May the best merchandise win: The law of non-trademark uses of sports logos. Marquette Sports Law Review, 14, 283-317.

Kaiser, J.C. (2005). Victor's not so little secret: Trademark dilution is difficult but not impossible to prove following Moseley v. V. Secret Catalogue, Inc. Chicago-Kent Law Review, 80, 425-448.

Kapferer, J. (1997). Strategic brand management. Dover, NH: Kogan Page.

Keller, K.L. (1993). Conceptualizing, measuring, and managing customer-based brand equity. Journal of Marketing, 57(1), 1-22. doi:10.2307/1252054

Kenny, D.A. (2013). Measuring model fit. Retrieved from http://davidakenny.net/cm/fit.htm

Knapp, D. (1999). The brand mindset. New York, NY: McGraw-Hill.

Knapp, D. (2008). The brand promise. New York, NY: McGraw-Hill.

Lanham Act, 15 U.S.C. § 1114(1)(a) (West 2005).

Lanham Act, 15 U.S.C. $\$ 1127$ (West 2006).

Lanham Act, 15 U.S.C. § 1125(a)(1) (West 2012).

Le Péru, A. (2004). Branding and territories: The conflict of applying domestic laws to universal trademarks (Doctoral dissertation, McGill University).

Lee, H., \& Cho, C. (2009). The matching effect of brand and sporting event personality: sponsorship implications. Journal of Sport Management, 23(1), 41-64.

Lee, H., \& Cho, C. (2012). Sporting event personality: scale development and sponsorship implications. International Journal of Sports Marketing \& Sponsorship, 14(1), 51-68.

Lee, T.R. (2004). Demystifying dilution. Boston University Law Review. Boston University. School of Law, 84, 859-944.

Lemley, M.A. (1999). The modern Lanham Act and the death of common sense. The Yale Law Journal, 108, 1687-1715. doi:10.2307/797447

Long, C. (2006). Dilution. Columbia Law Review, 106(5), 1029-1078.

Lutz, R.J. (1981). The role of attitude theory in marketing. In H.H. Kassarjian \& T.S. Robertson (Eds.), Perspectives in consumer behavior (3rd ed., pp. 233-250). Englewood Cliffs, NJ: Scott Foresman.

Lynch, J., \& Schuler, D. (1994). The match up effect of spokesperson and product congruence. Psychology and Marketing, 11(5), 417-445. doi:10.1002/mar.4220110502

MacKenzie, S.B., Lutz, R.J., \& Belch, G.E. (1986). The role of attitude toward the ad as a mediator of advertising effectiveness: A test of competing explanations. JMR, Journal of Marketing Research, 23(2), 130-143. doi:10.2307/3151660 
Magid, J.M., Cox, A.D., \& Cox, D.S. (2006). Quantifying brand image: Empirical evidence of trademark dilution. American Business Law Journal, 43, 1-42. doi:10.1111/j.17441714.2006.00010.x

Magliocca, G.N. (2001). One and inseparable: Dilution and infringement in trademark law. Minnesota Law Review, 85, 949-1036.

Manta, I.D. (2007). In search of validity: A new model for the content and procedural treatment of trademark infringement surveys. Cardozo Arts \& Entertainment Law Journal, $24,1027-1072$.

McCabe, K.B. (2000). Dilution-by-blurring: A theory caught in the shadow of trademark infringement. Fordham Law Review, 68, 1827-1874.

McCarthy, J.T. (2004). Proving a trademark has been diluted: Theories or fact? Houston Law Review, 41, 713-747.

McCrae, R.R., \& Costa, P.T. (1985). Updating Norman's “adequate taxonomy”: Intelligence and personality dimensions in natural language and in questionnaires. Journal of Personality and Social Psychology, 49(3), 710-721. doi:10.1037/0022-3514.49.3.710

McKenna, M.P. (2009). Testing modern trademark law's Theory of Harm. Iowa Law Review, 95, 63-117.

Morrin, M., \& Jacoby, J. (2000). Trademark dilution: Empirical measures for an elusive concept. Journal of Public Policy \& Marketing, 19(2), 265-276. doi:10.1509/ jppm.19.2.265.17137

Moseley et al. v. V. Secret Catalogue, Inc., et al. 537 U.S. 418 (2003).

Musante, M., Milne, G.R., \& McDonald, M.A. (1999). Sport sponsorship: Evaluating the sport and brand image match. International Journal of Sports Marketing \& Sponsorship, 1(1), 32-47.

Nike, Inc. v. Nikepal, Inc., 84 U.S.P.Q.2D (BNA) 1521 (E. D. Cal., Feb.27, 2007).

Ohm, P. (2013). Branding privacy. Minnesota Law Review, 97, 907-989.

Park, C.W., Milberg, S., \& Lawson, R. (1991). The role of product feature similarity and brand concept consistency. The Journal of Consumer Research, 18(2), 185-193. doi:10.1086/209251

Polaroid Corp. v. Polarad Electronics, Corp., 287 F.2d 492 (2d Cir. 1961).

Port, K.L. (2000). The congressional expansion of American trademark law: A civil law system in the making. Wake Forest Law Review, 35, 827-913.

Ratcliff, R. (1978). A theory of memory retrieval. Psychological Review, 85(2), 59-108. doi:10.1037/0033-295X.85.2.59

Roberts, K. (2005). Lovemarks. Brooklyn, NY: Powerhouse Books.

Roberts, K. (2006). The Lovemarks Effect. Brooklyn, NY: Powerhouse Books.

Schechter, F.I. (1927). The rational basis of trademark protection. Harvard Law Review, 40, 813-833. doi:10.2307/1330367

Shanti, A.O. (2001). Measuring fame: The use of empirical evidence in dilution actions. Marquette Intellectual Property Law Review, 5, 177-210.

Shuy, R. (2002). Linguistic battles in trademark disputes. New York, NY: Palgrave MacMillan.

Simonson, A.F. (1993). How and when do trademarks dilute: A behavioral framework to judge "likelihood" of dilution. Trademark Reporter, 83, 149-174.

Sweeney, J.C., \& Brandon, C. (2006). Brand personality: Exploring the potential to move from factor analytical to circumplex models. Psychology and Marketing, 23(8), 639-663. doi:10.1002/mar.20122

Thomas, J.R., Nelson, J.K., \& Silverman, S.J. (2011). Research methods in physical activity. Champaign, IL: Human Kinetics.

Thurmon, M.A. (2009). Recent developments in trademark law. Wake Forest Intellectual Property Law Journal, 9, 1-60.

Trademark Dilution Act, 15 U.S.C. § 1125(c)(1) (West 2012).

Trademark Dilution Act, 15 U.S.C. § 1125(c)(2) (West 2012). 
Trademark Dilution Act, 15 U.S.C. § 1125(c)(2)(A) (West 2012).

Tushnet, R. (2008). Gone in sixty milliseconds: Trademark law and cognitive science. Texas Law Review, 86, 507-568.

Vapnyar, V. (2003). Moseley v. V. Secret Catalogue, Inc.: Redefining the scope of the federal Weinberger v. Romero-Barcelo, 456 U.S. 305 (1982).

Young \& Rubicam. (2013). Brand asset valuator. Retrieved from http://young-rubicam.de/ tools-wissen/tools/brandasset-valuator/?lang=en 


\section{Appendix}

THIS IS A QUESTIONNAIRE TO STUDY HOW YOU PERCEIVE FAMOUS BRANDS AND

PROFESSIONAL SPORTS. IT WILL BE USED FOR ACADEMIC RESEARCH ONLY.

Your age:

Major:

I. How would you rate each of the following brands based on given adjectives?

( 1 = Not descriptive; 7 = Very descriptive $)$

\begin{tabular}{|l|ccccccc|ccccccc|}
\hline \multirow{2}{*}{ ADJECTIVES } & \multicolumn{1}{|c|}{ "Budweiser" } & \multicolumn{1}{c|}{ "NBA" } \\
& not & & \multicolumn{1}{c|}{ very } & not & \multicolumn{6}{c|}{ very } \\
\hline Down-to-earth & 1 & 2 & 3 & 4 & 5 & 6 & 7 & 1 & 2 & 3 & 4 & 5 & 6 & 7 \\
\hline Honest & 1 & 2 & 3 & 4 & 5 & 6 & 7 & 1 & 2 & 3 & 4 & 5 & 6 & 7 \\
\hline Wholesome & 1 & 2 & 3 & 4 & 5 & 6 & 7 & 1 & 2 & 3 & 4 & 5 & 6 & 7 \\
\hline Cheerful & 1 & 2 & 3 & 4 & 5 & 6 & 7 & 1 & 2 & 3 & 4 & 5 & 6 & 7 \\
\hline
\end{tabular}

\begin{tabular}{|c|c|c|}
\hline \multirow{2}{*}{ ADJECTIVES } & "Nike" & "NHL" \\
\hline & very & very \\
\hline Daring & $\begin{array}{lllllll}1 & 2 & 3 & 4 & 5 & 6 & 7\end{array}$ & $\begin{array}{lllllll}1 & 2 & 3 & 4 & 5 & 6 & 7\end{array}$ \\
\hline Spirited & $\begin{array}{lllllll}1 & 2 & 3 & 4 & 5 & 6 & 7\end{array}$ & $\begin{array}{lllllll}1 & 2 & 3 & 4 & 5 & 6 & 7\end{array}$ \\
\hline Imaginative & $\begin{array}{lllllll}1 & 2 & 3 & 4 & 5 & 6 & 7\end{array}$ & $\begin{array}{lllllll}1 & 2 & 3 & 4 & 5 & 6 & 7\end{array}$ \\
\hline Up-to-date & $\begin{array}{lllllll}1 & 2 & 3 & 4 & 5 & 6 & 7\end{array}$ & $\begin{array}{lllllll}1 & 2 & 3 & 4 & 5 & 6 & 7\end{array}$ \\
\hline
\end{tabular}

\begin{tabular}{|l|ccccccc|ccccccc|}
\hline \multirow{2}{*}{ ADJECTIVE } & \multicolumn{1}{|c|}{ "Master Card" } & \multicolumn{1}{c|}{ "PGA" } \\
& not & & \multicolumn{1}{c|}{ very } & not & & & \multicolumn{1}{c|}{ very } \\
\hline "Upper Class" & 1 & 2 & 3 & 4 & 5 & 6 & 7 & 1 & 2 & 3 & 4 & 5 & 6 & 7 \\
\hline "Charming" & 1 & 2 & 3 & 4 & 5 & 6 & 7 & 1 & 2 & 3 & 4 & 5 & 6 & 7 \\
\hline
\end{tabular}

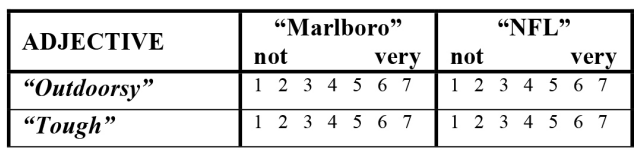

\begin{tabular}{|l|cccccc|cc|cccccc|}
\hline \multirow{2}{*}{ ADJECTIVE } & \multicolumn{1}{|c|}{ "Mercedes Benz" } & \multicolumn{1}{c|}{ "MLB” } \\
& not & & & very & not & & \multicolumn{1}{c|}{ very } \\
\hline Reliable & 1 & 2 & 3 & 4 & 5 & 6 & 7 & 1 & 2 & 3 & 4 & 5 & 6 & 7 \\
\hline Intelligent & 1 & 2 & 3 & 4 & 5 & 6 & 7 & 1 & 2 & 3 & 4 & 5 & 6 & 7 \\
\hline Successful & 1 & 2 & 3 & 4 & 5 & 6 & 7 & 1 & 2 & 3 & 4 & 5 & 6 & 7 \\
\hline
\end{tabular}

II. $\quad \underline{\text { Rate }}$ your favorability of brands $(1=$ Not like at all; $7=$ Really Like $)$

\begin{tabular}{|l|lllllll|}
\hline BRAND & \multicolumn{3}{|l}{$\begin{array}{l}\text { Not Like } \\
\text { At All }\end{array}$} & \multicolumn{4}{c|}{$\begin{array}{l}\text { Really } \\
\text { Like }\end{array}$} \\
\hline Master Card & 1 & 2 & 3 & 4 & 5 & 6 & 7 \\
\hline Marlboro & 1 & 2 & 3 & 4 & 5 & 6 & 7 \\
\hline Nike & 1 & 2 & 3 & 4 & 5 & 6 & 7 \\
\hline Budweiser & 1 & 2 & 3 & 4 & 5 & 6 & 7 \\
\hline Benz & 1 & 2 & 3 & 4 & 5 & 6 & 7 \\
\hline
\end{tabular}

\begin{tabular}{|l|lllllll|}
\hline BRAND & \multicolumn{3}{|l}{$\begin{array}{l}\text { Not Like } \\
\text { At All }\end{array}$} & \multicolumn{4}{c|}{$\begin{array}{l}\text { Really } \\
\text { Like }\end{array}$} \\
\hline PGA & 1 & 2 & 3 & 4 & 5 & 6 & 7 \\
\hline NHL & 1 & 2 & 3 & 4 & 5 & 6 & 7 \\
\hline NFL & 1 & 2 & 3 & 4 & 5 & 6 & 7 \\
\hline NBA & 1 & 2 & 3 & 4 & 5 & 6 & 7 \\
\hline MLB & 1 & 2 & 3 & 4 & 5 & 6 & 7 \\
\hline
\end{tabular}


III. How would you rate the given statements with respect to the brands/events?

\begin{tabular}{|l|l|lllllll|}
\hline $\begin{array}{c}\text { This brand provides distinctive } \\
\text { "products or services" }\end{array}$ \\
$\bullet \quad 7=$ Strongly Agree (SA) \\
$\bullet \quad 1=$ Strongly Disagree (SD) \\
\hline BRAND & SD & & \multicolumn{1}{c|}{ SA } \\
\hline Master Card & 1 & 2 & 3 & 4 & 5 & 6 & 7 \\
\hline Marlboro & 1 & 2 & 3 & 4 & 5 & 6 & 7 \\
\hline Nike & 1 & 2 & 3 & 4 & 5 & 6 & 7 \\
\hline Budweiser & 1 & 2 & 3 & 4 & 5 & 6 & 7 \\
\hline Benz & 1 & 2 & 3 & 4 & 5 & 6 & 7 \\
\hline
\end{tabular}

\begin{tabular}{|l|l|lllllll|}
\hline $\begin{array}{l}\text { This event provides distinctive } \\
\text { "experience, products or services" }\end{array}$ \\
$\bullet \quad 7=$ Strongly Agree (SA) \\
$\bullet \quad 1=$ Strongly Disagree (SD) \\
\hline SPORT EVENT & SD & & & & SA \\
\hline PGA & 1 & 2 & 3 & 4 & 5 & 6 & 7 \\
\hline NHL & 1 & 2 & 3 & 4 & 5 & 6 & 7 \\
\hline NFL & 1 & 2 & 3 & 4 & 5 & 6 & 7 \\
\hline NBA & 1 & 2 & 3 & 4 & 5 & 6 & 7 \\
\hline MLB & 1 & 2 & 3 & 4 & 5 & 6 & 7 \\
\hline
\end{tabular}

\begin{tabular}{|l|l|lllllll|}
\hline \multicolumn{1}{|c|}{$\begin{array}{c}\text { This brand provides some } \\
\text { advantages to its users }\end{array}$} \\
$\bullet \quad 7=$ Strongly Agree (SA) \\
$\bullet \quad 1=$ Strongly Disagree (SD) \\
\hline BRAND & SD & & & SA \\
\hline Master Card & 1 & 2 & 3 & 4 & 5 & 6 & 7 \\
\hline Marlboro & 1 & 2 & 3 & 4 & 5 & 6 & 7 \\
\hline Nike & 1 & 2 & 3 & 4 & 5 & 6 & 7 \\
\hline Budweiser & 1 & 2 & 3 & 4 & 5 & 6 & 7 \\
\hline Benz & 1 & 2 & 3 & 4 & 5 & 6 & 7 \\
\hline
\end{tabular}

\begin{tabular}{|l|llllllll|}
\hline \multicolumn{1}{|c|}{$\begin{array}{c}\text { This event provides some type of } \\
\text { benefits to its fans }\end{array}$} \\
$\bullet \quad 7=$ Strongly Agree (SA) \\
$\bullet \quad 1=$ Strongly Disagree (SD) \\
\hline SPORT EVENT & SD & & \\
\hline PGA & 1 & 2 & 3 & 4 & 5 & 6 & 7 \\
\hline NHL & 1 & 2 & 3 & 4 & 5 & 6 & 7 \\
\hline NFL & 1 & 2 & 3 & 4 & 5 & 6 & 7 \\
\hline NBA & 1 & 2 & 3 & 4 & 5 & 6 & 7 \\
\hline MLB & 1 & 2 & 3 & 4 & 5 & 6 & 7 \\
\hline
\end{tabular}

\begin{tabular}{|l|l|lllllll|}
\hline \multicolumn{1}{|c|}{$\begin{array}{c}\text { Overall, this brand has } \\
\text { "distinctive" value }\end{array}$} \\
$\bullet \quad 7$ = Strongly Agree (SA) \\
• $1=$ Strongly Disagree (SD) \\
\hline BRAND & SD & & & & SA \\
\hline Master Card & 1 & 2 & 3 & 4 & 5 & 6 & 7 \\
\hline Marlboro & 1 & 2 & 3 & 4 & 5 & 6 & 7 \\
\hline Nike & 1 & 2 & 3 & 4 & 5 & 6 & 7 \\
\hline Budweiser & 1 & 2 & 3 & 4 & 5 & 6 & 7 \\
\hline Benz & 1 & 2 & 3 & 4 & 5 & 6 & 7 \\
\hline
\end{tabular}

\begin{tabular}{|l|l|lllllll|}
\hline \multicolumn{1}{|c|}{$\begin{array}{c}\text { Overall, this sport event has } \\
\text { "distinctive" brand value }\end{array}$} \\
• $7=$ Strongly Agree (SA) \\
• $1=$ Strongly Disagree (SD) \\
\hline SPORT EVENT & SD & & & \\
\hline PGA & 1 & 2 & 3 & 4 & 5 & 6 & 7 \\
\hline NHL & 1 & 2 & 3 & 4 & 5 & 6 & 7 \\
\hline NFL & 1 & 2 & 3 & 4 & 5 & 6 & 7 \\
\hline NBA & 1 & 2 & 3 & 4 & 5 & 6 & 7 \\
\hline MLB & 1 & 2 & 3 & 4 & 5 & 6 & 7 \\
\hline
\end{tabular}

THANK YOU VERY MUCH!! 